\title{
Optimizing the tray dryer temperature and time of white corn flour culture
}

\author{
${ }^{1}$ Hunaefi, D., ${ }^{2, *}$ Rahmawati, R., ${ }^{3}$ Saputra, D., ${ }^{4}$ Maulani, R.R. and ${ }^{1}$ Muhandri, T. \\ ${ }^{1}$ Department of Food Science and Technology and SEAFAST Center, IPB University (IPB), Kampus IPB \\ Darmaga PO Box 220 Bogor 16002, Indonesia \\ ${ }^{2}$ Food Technology Program, Sahid University, Jl Prof. Dr. Supomo SH. Nomor 84, Jakarta Selatan 12870, \\ Indonesia \\ ${ }^{3}$ PT Sigma Fazza Sintesa, Harvest City Cluster Florentina F6 no. 15 Cilengsi, Jawa Barat 16820, Indonesia \\ ${ }^{4}$ Study Program of Postharvest Technology, School of Life Science and Technology, Institut Teknologi \\ Bandung, Jl. Ganeca 10 Bandung 40132
}

\begin{abstract}
Article history:
Received: 8 December 2020

Received in revised form: 24

January 2021

Accepted: 13 April 2021

Available Online: 19

September 2021
\end{abstract}

\section{Keywords:}

AC culture,

CC culture,

RSM,

Tray dryer,

White corn flour

\section{DOI:}

https://doi.org/10.26656/fr.2017.5(5).718

\begin{abstract}
This research aimed to optimize the tray dryer temperature and time of white corn flour culture by Response Surface Methodology (RSM). There were two cultures used in this research, namely Amylolytic Culture (AC) and Complete Culture (CC). AC consisted of Penicillium citrinum, Aspergillus niger, Acremonium strictum, and Candida famata, while CC consisted of Penicillium chrysogenum, Penicillium citrinum, Aspergillus niger, Rhizopus stolonifer, Rhizopus oryzae, Fusarium oxysporum, Acremonium strictum, Candida famata, Kodamaea ohmeri and Candida krusei/incospicua. The independent variables in this study were drying temperature and time, where the quality indicators used were total viability of mold and yeast, water content, water activity, and $\mathrm{pH}$. This research used a factor response surface methodology. Data were analyzed by ANOVA with an $\alpha$ level of $95 \%$. The result of this research showed that the optimum drying process for AC starter was $40^{\circ} \mathrm{C}$ for $10 \mathrm{hrs}$, with characteristic response viability $8.8 \times 10^{7} \mathrm{CFU} / \mathrm{g}$, water activity 0.43 , water content $8.90 \%$, and $\mathrm{pH} 4.05$. CC starter showed an optimum drying process at $49^{\circ} \mathrm{C}$ for $4.5 \mathrm{hrs}$, with characteristic response viability $4.9 \times 10^{7} \mathrm{CFU} / \mathrm{g}$, water activity 0.49 , water content $7.02 \%$, and $\mathrm{pH} 3.95$. The optimum tray dryer temperatures and times were achieved for $\mathrm{AC}$ and $\mathrm{CC}$ starters.
\end{abstract}

\section{Introduction}

White corn flour is a food commodity with limited use. This flour has a weakness, such as high viscosity, with high retrograde, the paste undergoes syneresis during storage, and low paste stability at high temperature and low pH (Aini et al., 2010). Farasara et al. (2014) showed that fermentation with the addition of indigenous mould and yeast culture could change the characteristic of white corn flour paste of Anoman 1 after $36 \mathrm{hrs}$ fermentation. The indigenous mould and yeast resulted from the isolation and identification of microorganisms in the spontaneous fermentation of white corn varieties of Anoman 1 and was grouped into AC and CC starters (Rahmawati et al., 2013). To simplify the fermentation process and quality control, indigenous mould and yeast cultures were made the dried starter. Dried starters have been produced using sun drying and oven drying methods (Rahmawati et al., 2017). The sun-drying method was carried out by drying for 7 days, between 8.00 and 15.00 WIB, with a total drying time of $48 \mathrm{hrs}$. AC starters produced the best characteristics with viability of $2.7 \times 10^{8} \mathrm{CFU} / \mathrm{g}$ and a moisture content of $13.34 \%$. The sun-drying method has the disadvantage of uncontrolled temperatures and long drying times.

The weakness of this sun drying method may cause the growth of microorganisms to be less optimal. The oven-drying method was carried out at $40^{\circ} \mathrm{C}$ for 24,48 and 72 hrs. The starter CC, which was dried for $48 \mathrm{hrs}$, had the best characteristics with a viability of $5.8 \times 10^{8}$ $\mathrm{CFU} / \mathrm{g}$ and a moisture content of $12.57 \%$. This method has the advantage of being temperature controlled but still takes a long time to dry. In addition, the starter was still wet in the oven when drying for $24 \mathrm{hrs}$ (Rahmawati 
et al., 2017). A more efficient and faster drying method is therefore needed, namely by using a tray dryer.

Rahmawati et al. (2019) have carried out the drying method for white corn starter using a tray dryer, where drying was conducted at 40 and $50^{\circ} \mathrm{C}$ for $1.5-6 \mathrm{hrs}$. This method has a more controlled temperature than the sunshine method and with a shorter time than the oven method. The tray dryer method can reduce the drying time and increase the efficiency of hot air contact with the material (Sari et al., 2017). The dried starter produced by Rahmawati et al. (2019) did not have optimal characteristics where the viability of the starters was $<10^{6} \mathrm{CFU} / \mathrm{g}$ and the water content were $>10 \%$. Therefore, it is necessary to optimize the starter drying process which includes temperature and drying time using the tray dryer method. The optimization of the drying process for starters was carried out by using the $\mathrm{D}$ -optimal design of the Response Surface Methodology (RSM) method. RSM is a statistical and mathematical technique used primarily for the development, improvement and optimization of the production process (Myers et al., 2009). Based on the description above, this research aimed to optimize the tray dryer temperature and time of white corn flour culture by RSM.

\section{Materials and methods}

\subsection{AC and CC starter preparation}

AC consists of Penicillium citrinum, Aspergillus niger, Acremonium strictum, and Candida famata, while CC consists of Penicillium chrysogenum, Penicillium citrinum, Aspergillus niger, Rhizopus stolonifer, Rhizopus oryzae, Fusarium oxysporum, Acremonium strictum, Candida famata, Kodamaea ohmeri and Candida krusei/incospicua. These microorganisms used were previously isolated and identified from spontaneous fermentation of corn grits (Rahmawati et al., 2013)

A loop of each mould was streaked onto fresh Potato Dextrose Agar (PDA) slant and incubated for 5 days at $30^{\circ} \mathrm{C}$. After five days, moulds were harvested by scraping, then suspended in $10 \mathrm{~mL}$ sterile water and appropriately dissolved to count using Mariendfeld haemocytometer. Yeast culture was prepared as above, but incubation was carried out for two days at $30^{\circ} \mathrm{C}$. Yeast was also calculated using Mariendfeld haemocytometer (Rahmawati et al., 2017).

\subsection{Optimization using RSM}

The Response Surface Methodology (RSM) method was used to maximize the drying process by using the Design Expert ${ }^{\circledR} 7.0$ (DX7) statistical application. The experimental design aims to achieve an optimum response by combining several components (Keshani et al., 2010). The mixed design is D-optimal where it was necessary to have a lower limit (-1) and an upper limit $(+1)$. The independent variables in this study were drying temperature and time. The experimental design was based on RSM (Table 1).

Table 1. Independent variables and the level used in the design process

\begin{tabular}{ccc}
\hline \multirow{2}{*}{ Independent variables } & \multicolumn{2}{c}{ Limits } \\
\cline { 2 - 3 } & Lower $(-1)$ & Upper $(+1)$ \\
\hline Temperatures $\left({ }^{\circ} \mathrm{C}\right)$ & 40 & 50 \\
Times $($ et al. $)$ & 0 & 10 \\
\hline
\end{tabular}

The parameters of the experiment were drying time (hrs) and drying temperature $\left({ }^{\circ} \mathrm{C}\right)$. Drying time between $0-10 \mathrm{hrs}$ and drying temperature between $40-50^{\circ} \mathrm{C}$ (Rahmawati et al., 2017). The AC and CC starter qualities were determined based on total viability mouldyeast, moisture content (oven method), water activity (Rotronic Hygrolab water activity meter) and $\mathrm{pH}$ (Benchtop pH meter Mettler Toledo Seven Compact).

There were criteria for each variable and response when performing optimization. The observed response was viability with an importance level of $5(+++++)$, while the response to moisture, aw and $\mathrm{pH}$ had an importance level of $3(+++)$. The importance value will determine the process conditions that were closest to the target response. The chosen optimal combination is the one having the highest desired value.

\subsection{Making starters and drying with a tray dryer}

$\mathrm{AC}$ and $\mathrm{CC}$ starter culture made by sterilizing corn flour, then put it into a sterile basin and adding sterile distilled water as much as $2 / 3$ of the total weight of cornflour. Prepared culture suspensions (AC) containing $10^{6} \mathrm{CFU} / \mathrm{mL}$ per microorganism, then piped as much as $10 \%$ of the amount of water used. After that, all stir until homogeneous and put $17 \mathrm{~g}$ in each petri dish. Petri dishes were then incubated at $30^{\circ} \mathrm{C}$ for 5 days. Furthermore, the dough is dried using a tray dryer with a range of $40-50^{\circ} \mathrm{C}$ for $0-10 \mathrm{hrs}$. The dried $\mathrm{AC}$ and $\mathrm{CC}$ yeast mould culture was made powder using a blender that has been sprayed with $70 \%$ alcohol (Rahmawati et al., 2019)

\subsection{Response measurement}

Response measurements were carried out on the dried powder sample that was inserted into a plastic clip containing silica gel. The responses measured included total mould and yeast viability, aw, moisture content, and $\mathrm{pH}(\mathrm{AOAC}, 2006)$.

\subsection{Verification of optimization results}

The results were validated at the highest desirability 
point for $\mathrm{AC}$ and $\mathrm{CC}$ starters respectively. The $\mathrm{AC}$ and $\mathrm{CC}$ starting process was repeated directly using the optimal drying process. In addition, the test process included direct measurement of the overall yeast mold viability, moisture contents, water activity and $\mathrm{pH}$ to generate the actual response variable.

\subsection{Data analysis}

The data analysis technique used in this study includes linear $(\mathrm{y}=\mathrm{ax}+\mathrm{b})$ models, quadratic $\left(\mathrm{y}=\mathrm{ax}^{2}+\right.$ $\mathrm{bx}+\mathrm{c})$ and 2FI models, using the Response Surface Methodology.

\section{Results and discussion}

\subsection{Viability test}

The viability of the total yeast mould starter could be seen in Table 2. Based on Table 2, we can see that the total value of yeast mould $\mathrm{AC}$ and $\mathrm{CC}$ starters ranged from $10^{7}-10^{8} \mathrm{CFU} / \mathrm{g}$ at drying temperatures $<50^{\circ} \mathrm{C}$. In the meantime, the viability value of the yeast mould $\mathrm{AC}$ and $\mathrm{CC}$ starters at drying temperatures $50^{\circ} \mathrm{C}$ and drying time of 7.3 to $10 \mathrm{hrs}$ were 0 . According to Pitt and Hocking (2009), Aspergillus Niger may grow at a minimum temperature of $6-8^{\circ} \mathrm{C}$, the maximum temperature of $45-47^{\circ} \mathrm{C}$, and optimal growth of 35 to $37^{\circ} \mathrm{C}$, while Rhizopus oryzae can grow at a temperature of 7 to $42^{\circ} \mathrm{C}$ with an optimal growth temperature of approximately $37^{\circ} \mathrm{C}$. Candida krusei can grow optimally at a temperature of $37^{\circ} \mathrm{C}$ (Scorzoni, 2013). The mould and yeast, in the beginning, were suspected to die at $50^{\circ} \mathrm{C}$ with a drying time of more than $7.3 \mathrm{hrs}$. Passamani et al. (2014) stated that $A$. niger may grow optimal at temperatures between 24 to $37^{\circ} \mathrm{C}$, aw greater than 0.95 , and $\mathrm{pH}$ levels between 4 to 6.5. Ayinla et al. (2017) have found that Rhizopus oryzae ZAC3 can grow in the $\mathrm{pH}$ of 4.0 to 8.0 and temperature of 25 to $55^{\circ} \mathrm{C}$. Besides that, Samaranayake and Samaranayake (1994) stated that $C$. krusei is a mesophile that can only grow at temperatures up to $45^{\circ} \mathrm{C}$.

The heat resistance of microorganisms is different, which is represented by the $\mathrm{D}$ value. The $\mathrm{D}$ value is defined as the time in mins at a given temperature which is reducing $90 \%$ or a logarithm of the number of spores or certain vegetative cells. Rahmawati et al. (2019) reported that the $\mathrm{D}$ value of $\mathrm{AC}$ and $\mathrm{CC}$ at temperatures of $40^{\circ} \mathrm{C}$ was 271.86 mins $(4.5 \mathrm{hrs})$ and $523.10 \mathrm{mins}(8.7$ hrs) respectively, while at $50^{\circ} \mathrm{C}$ was 147.06 mins $(2.45$ hrs) and 127.93 mins (2.13 hrs) respectively.

\subsection{Moisture content}

Water content and water activity (aw) are closely linked with starters' shelf-life. These two parameters are indicators of the availability of water in food for the survival of microorganisms. In addition to affecting chemical changes, the water content in food also determines the microbial content of foods (Herawati, 2008). Products that have higher water content will relatively have a shorter shelf life (Amanto et al., 2015). Table 2 tabulates the water content for $\mathrm{AC}$ and $\mathrm{CC}$ starters.

The initial moisture content of the AC starter was $56.00 \%$ and $\mathrm{CC}$ starter was $57.30 \%$. In this study, the desired water content was $<10 \%$. With this water content value, it was hoped that the microorganisms will remain alive but did not carry out the metabolic activity. The dried starter that drying at $50^{\circ} \mathrm{C}$ tended to have a lower moisture content than a lower temperature $\left(40^{\circ} \mathrm{C}\right)$.

Table 2. The viability and water content responses for AC and CC starter as the results of RSM optimization

\begin{tabular}{ccccccc}
\hline \multirow{2}{*}{ Treatment Drying Temperature $\left({ }^{\circ} \mathrm{C}\right)$} & \multirow{2}{*}{$\begin{array}{c}\text { Drying } \\
\text { time }(\mathrm{Hr})\end{array}$} & \multicolumn{2}{c}{ Viability $(\mathrm{CFU} / \mathrm{g})$} & \multicolumn{2}{c}{ Water content $(\%)$} \\
\cline { 3 - 7 } & & 0 & $6.75 \times 10^{8}$ & $2.40 \times 10^{8}$ & 56.00 & 57.30 \\
2 & 40 & 4.5 & $3.05 \times 10^{8}$ & $3.00 \times 10^{8}$ & 11.67 & 11.01 \\
3 & 40 & 4.5 & $5.50 \times 10^{8}$ & $2.70 \times 10^{8}$ & 12.52 & 11.29 \\
4 & 40 & 7.3 & $7.50 \times 10^{8}$ & $1.85 \times 10^{8}$ & 8.66 & 10.98 \\
5 & 40 & 10 & $5.00 \times 10^{8}$ & $1.70 \times 10^{8}$ & 8.59 & 10.26 \\
6 & 40 & 0 & $5.00 \times 10^{8}$ & $3.00 \times 10^{8}$ & 56.00 & 57.30 \\
7 & 43 & 8.6 & $1.00 \times 10^{8}$ & $2.40 \times 10^{7}$ & 9.16 & 11.53 \\
8 & 43 & 0 & $5.00 \times 10^{8}$ & $3.00 \times 10^{8}$ & 55.90 & 57.30 \\
9 & 45 & 5.9 & $1.40 \times 10^{8}$ & $5.20 \times 10^{7}$ & 8.91 & 9.11 \\
10 & 45 & 10 & $1.40 \times 10^{7}$ & $4.50 \times 10^{7}$ & 10.61 & 10.65 \\
11 & 45 & 0 & $3.80 \times 10^{8}$ & $7.80 \times 10^{8}$ & 55.90 & 57.30 \\
12 & 50 & 4.5 & $7.50 \times 10^{7}$ & $3.00 \times 10^{7}$ & 5.65 & 5.44 \\
13 & 50 & 4.5 & $2.00 \times 10^{7}$ & $1.10 \times 10^{7}$ & 5.79 & 5.22 \\
14 & 50 & 7.3 & 0 & 0 & 8.66 & 10.98 \\
15 & 50 & 10 & 0 & 0 & 8.91 & 10.28 \\
16 & 50 & 10 & 0 & 0 & 8.80 & 10.34 \\
\hline
\end{tabular}


According to Rahmawati et al. (2019), it caused the drying rate at $50^{\circ} \mathrm{C}$ was faster than at $40^{\circ} \mathrm{C}$. As we know that a higher drying rate resulted in a faster drying time.

Drying time can also reduce the material's moisture content. At a temperature of $40^{\circ} \mathrm{C}$ with different drying times, the moisture content of $\mathrm{AC}$ starters decreased from $56.00 \%$ to $11.67 \%$ after $4.5 \mathrm{hrs}$ of drying and continued to dry to $8.59 \%$ after $10 \mathrm{hrs}$ of drying. Likewise, with CC starters, the moisture content of CC starters decreased from $57.30 \%$ to $11.01 \%$ after $4.5 \mathrm{hrs}$ of drying and continued to dry to $10.26 \%$ after $10 \mathrm{hrs}$ of drying at $40^{\circ} \mathrm{C}$. In line with Fitriani (2008) statement, that drying temperature and time higher will evaporate water molecules more than lower temperature and time. Besides that, this condition will make the products ability to release water from its surface to be greater and it will cause lowered water content. Abasi et al. (2009) reported that the temperature affected moisture content. The moisture content of the samples decreased with increasing temperature, from 2.72 to $1.15 \% \mathrm{db}$, for drying temperature of $60^{\circ} \mathrm{C}$ to $90^{\circ} \mathrm{C}$, respectively.

\subsection{Water activities value}

Overall, mould can live at a minimum water activity value. Aspergillus lives at a minimum water activity of 0.98, Rhizopus 0.93, and Penicillium 0.99, where yeast can usually live around 0.88-0.94 (Muchtadi and Sugiono, 2013). A low aw value can make starters' microorganisms dormant. $\mathrm{AC}$ and $\mathrm{CC}$ starter were expected to have a longer shelf life. Table 3 showed the water activity of the $\mathrm{AC}$ and $\mathrm{CC}$ starter.

When starters are dried for a long period of time, the water content will decrease, and the water activity starters will decrease as well. This is in line with Leviana and Paramita's research (2017), where the increase in the drying temperature will cause more water to evaporate. This will decrease the water content. Likewise, with the water activity value, the increase of drying time caused the water activity value in the material to decrease (Chen, 2019).

\section{$3.4 \mathrm{pH}$ value}

During the incubation process, the $\mathrm{pH}$ value of both $\mathrm{AC}$ and $\mathrm{CC}$ starters decreased, which becomes slightly sour (3.9-4.5) and was accompanied by a distinctive fermentation aroma. Table 3 shows the $\mathrm{pH}$ value for $\mathrm{AC}$ and CC starters. This indicated that the filler substrate (carbohydrates) has been metabolized by the microorganisms added to simpler compounds such as ethanol, carbon dioxide, and organic acids that can lower the $\mathrm{pH}$ value. In the fermentation process, metabolism occurs from the activity of organic acid-producing microorganisms, thereby reducing the $\mathrm{pH}$ (Anggraeni and Yuwono, 2014). According to Rahmawati et al. (2019), the initial $\mathrm{pH}$ value of $\mathrm{AC}$ and $\mathrm{CC}$ was around 4.00 , where this value was appropriate for microorganism growth. The decrease in $\mathrm{pH}$ value was due to the activity of microorganisms that converted carbohydrates into acids during the fermentation process.

\subsection{Mathematical model relationship between process parameters and response}

Table 4 shows the math model of the drying process parameter as a response of the AC starter and Table 5 for $\mathrm{CC}$ starter model. The linear model indicated that only temperature and drying time influence the response, but not the interactions between them. The quadratic model

Table 3. The water activity and $\mathrm{pH}$ value responses for $\mathrm{AC}$ and $\mathrm{CC}$ starter as the results of RSM optimization

\begin{tabular}{ccccccc}
\hline \multirow{2}{*}{ Treatment Drying Temperature $\left({ }^{\circ} \mathrm{C}\right)$} & \multirow{2}{*}{$\begin{array}{c}\text { Drying } \\
\text { time }(\mathrm{Hr})\end{array}$} & \multicolumn{2}{c}{ Water Activity } & \multicolumn{2}{c}{$\mathrm{pH}$ value } \\
\cline { 4 - 6 } 1 & 40 & 0.0 & 0.929 & 0.945 & 4.20 & 4.15 \\
2 & 40 & 4.5 & 0.460 & 0.474 & 4.22 & 4.50 \\
3 & 40 & 4.5 & 0.454 & 0.465 & 4.26 & 4.50 \\
4 & 40 & 7.3 & 0.430 & 0.426 & 4.00 & 4.65 \\
5 & 40 & 10.0 & 0.433 & 0.421 & 3.95 & 4.60 \\
6 & 43 & 0.0 & 0.929 & 0.945 & 4.28 & 4.20 \\
7 & 43 & 8.6 & 0.558 & 0.645 & 4.05 & 4.60 \\
8 & 45 & 0.0 & 0.929 & 0.959 & 4.28 & 4.20 \\
9 & 45 & 5.9 & 0.518 & 0.570 & 4.20 & 4.10 \\
10 & 45 & 10.0 & 0.449 & 0.478 & 4.26 & 4.23 \\
11 & 50 & 0.0 & 0.942 & 0.959 & 4.20 & 4.12 \\
12 & 50 & 4.5 & 0.460 & 0.474 & 4.33 & 4.22 \\
13 & 50 & 4.5 & 0.454 & 0.438 & 4.50 & 4.20 \\
14 & 50 & 7.3 & 0.438 & 0.426 & 4.40 & 4.31 \\
15 & 50 & 10.0 & 0.372 & 0.356 & 4.44 & 4.28 \\
16 & 50 & 10.0 & 0.380 & 0.367 & 4.50 & 4.40 \\
\hline
\end{tabular}


Table 4. The math model of drying proses parameter as a response of the AC starter

\begin{tabular}{|c|c|c|c|c|c|c|c|}
\hline Parameter & $\begin{array}{l}\text { Math } \\
\text { model }\end{array}$ & $\begin{array}{l}\text { Significance } \\
\text { model }(p)\end{array}$ & Lack of fit & R squared & $\begin{array}{l}\text { Adj } R^{2} \\
\text { model }\end{array}$ & $\begin{array}{c}\text { Pred } R^{2} \\
\text { model }\end{array}$ & $\begin{array}{c}\text { Adeq } \\
\text { precision }\end{array}$ \\
\hline Viability (CFU/g) & Linear & $\begin{array}{c}0.0123 \\
\text { (significant) }\end{array}$ & $\begin{array}{c}0.3702 \\
\text { (not significant) }\end{array}$ & 0.6237 & 0.5401 & 0.3511 & 6.248 \\
\hline Water content (\%) & $2 \mathrm{FI}$ & $\begin{array}{c}0.0016 \\
\text { (significant) }\end{array}$ & $\begin{array}{c}0.0404 \\
\text { (significant) }\end{array}$ & 0.8382 & 0.7775 & 0.6959 & 10.565 \\
\hline Water activity $\left(\mathrm{a}_{\mathrm{w}}\right)$ & Quadratic & $\begin{array}{c}0.0440 \\
\text { (significant) }\end{array}$ & $\begin{array}{c}0.0021 \\
\text { (significant) }\end{array}$ & 0.7950 & 0.6242 & 0.3560 & 7.238 \\
\hline $\mathrm{pH}$ & $2 \mathrm{FI}$ & $\begin{array}{c}0.0002 \\
\text { (significant) }\end{array}$ & $\begin{array}{c}0.6288 \\
\text { (not significant) }\end{array}$ & 0.8989 & 0.861 & 0.7554 & 13.784 \\
\hline \multicolumn{8}{|c|}{ Adj: Adjusted, Pred: Predicted, Adeq: Adequate } \\
\hline Parameter & $\begin{array}{l}\text { Math } \\
\text { model }\end{array}$ & $\begin{array}{l}\text { Significance } \\
\text { model }(p)\end{array}$ & Lack of fit & R squared & $\begin{array}{l}\text { Adj } R^{2} \\
\text { model }\end{array}$ & $\begin{array}{c}\text { Pred } R^{2} \\
\text { model }\end{array}$ & $\begin{array}{c}\text { Adeq } \\
\text { precision }\end{array}$ \\
\hline Viability (CFU/g) & Quadratic & $\begin{array}{c}0.0474 \\
\text { (significant) }\end{array}$ & $\begin{array}{c}0.9033 \\
\text { (not significant) }\end{array}$ & 0.7894 & 0.6139 & 0.2087 & 5.656 \\
\hline Water content $(\%)$ & $2 \mathrm{FI}$ & $\begin{array}{c}0.0023 \\
\text { (significant) }\end{array}$ & $\begin{array}{c}0.0019 \\
\text { (significant) }\end{array}$ & 0.8209 & 0.7537 & 0.6636 & 8.499 \\
\hline Water activity $\left(\mathrm{a}_{\mathrm{w}}\right)$ & & $\begin{array}{l}0.0616 \text { (not } \\
\text { significant) }\end{array}$ & $\begin{array}{c}0.0163 \\
\text { (significant) }\end{array}$ & 0.7679 & 0.5746 & 0.2841 & 6.541 \\
\hline $\mathrm{pH}$ & Quadratic & $\begin{array}{c}0.0193 \\
\text { (significant) }\end{array}$ & $\begin{array}{c}0.0769 \\
\text { (not significant) }\end{array}$ & 0.8479 & 0.7211 & 0.3705 & 6.974 \\
\hline
\end{tabular}

Adj: Adjusted, Pred: Predicted, Adeq: Adequate

showed that each factor influences the response and interaction between temperature and drying time. The 2FI model means the response is influenced by the temperature-drying interaction.

\subsection{Effect of drying process on starters viability}

Rahmawati et al. (2017) have dried the starter culture using an oven with a temperature below $40^{\circ} \mathrm{C}$ resulted in the wet starters (not yet dry). It showed that the starter could be dried at the lowest $40^{\circ} \mathrm{C}$ temperature. However, the drying process using a tray drier cannot generate heat if the temperature is less than $40^{\circ} \mathrm{C}$ were used. Based on this, the drying temperature used was up to $50^{\circ} \mathrm{C}$ (Rahmawati et al., 2019). The results showed that drying at $50^{\circ} \mathrm{C}$ for $6 \mathrm{hrs}$ still produced the number of microorganisms that met the minimum requirements for the viability of starter microorganisms $\left(10^{6} \mathrm{CFU} / \mathrm{g}\right)$. These results were in line with Oliveira et al. (2002) where a good fermented drink produced by the number

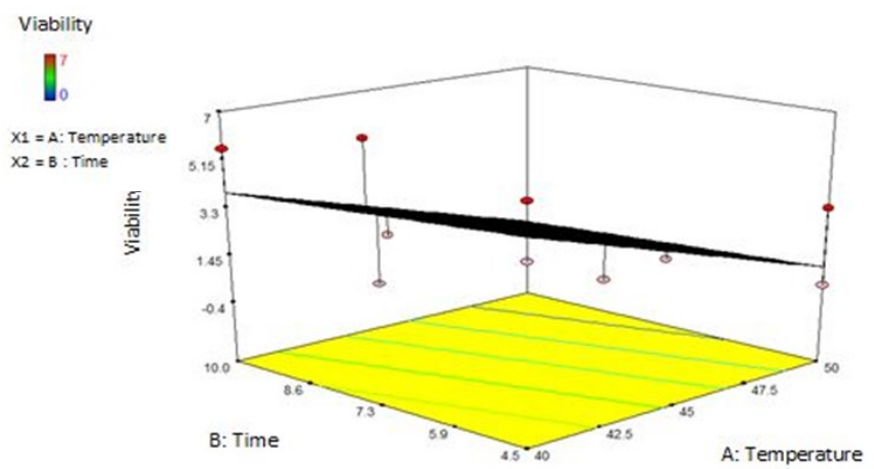

Figure 1. A 3D graphical combination between temperature and drying time to the viability response of AC starters. of bacteria was at least $5.3 \times 10^{6} \mathrm{CFU} / \mathrm{mL}$.

Thus, drying starters at a temperature of $40-50^{\circ} \mathrm{C}$ were expected to maintain a significant total viability mold and yeast. Figure 1 and Figure 2 show the graph of the relationship between temperature and drying time on the viability response of $\mathrm{AC}$ and $\mathrm{CC}$ starters respectively.

Based on the graph in Figure 1, an increase in temperature and drying time with a tray dryer caused a decrease in yeast viability on the starters. At a temperature of $50^{\circ} \mathrm{C}$. with a drying time of about $7.3 \mathrm{hrs}$, a value of 0 was produced. It indicates the absence of mould-yeast during the analysed. AC starters are mostly yeast. At this temperature and drying time, the yeast on AC starters was suspected to die. Vegetative yeast cells are killed with humid heat at $50-60^{\circ} \mathrm{C}$ in $10-15$ mins (Pelczar, 2012).

Figure 1 provides an overview of the AC-starters

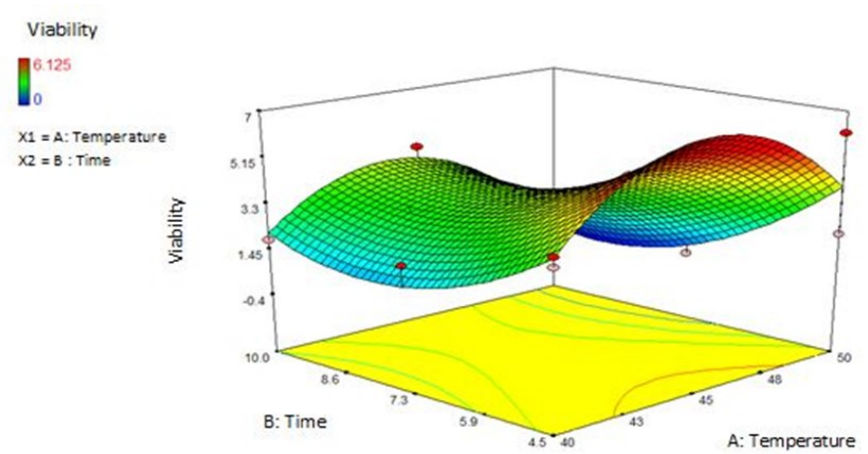

Figure 2. A 3D graphical combination between temperature and drying time to the viability response of CC starters 
viability response model. The red colour in the figure showed a high viability value, while the blue colour showed a low viability value. Microbes have different heat resistance as expressed by Rahmawati et al. (2019), the calculation results showed that the values of $\mathrm{D}$ starters $\mathrm{AC}$ and $\mathrm{CC}$ at $40^{\circ} \mathrm{C}$ were 271.86 mins (4.5 hrs) and $523.10 \mathrm{mins}(8.7 \mathrm{hrs})$ while at $50^{\circ} \mathrm{C}$ were 147.06 mins (2.45 hrs) and $127.93 \mathrm{mins}(2.13 \mathrm{hrs})$ respectively. $\mathrm{AC}$ starters were more heat-resistant. It caused $\mathrm{AC}$ starter to contain fewer types of microbes, so, when making starter cultures the competition between microbes was lower. This resulted in more available microbes. It was indicated by the higher initial microbial viability than $\mathrm{CC}$ starter.

The program selected model for appropriate viability response is a linear model with an $\mathrm{R}^{2}$ value of 0.6237 . AC mould-yeast viability response model has a $0.0123 p$ -value (Prob $>$ F). This showed that the model can still describe the viability response (AC), as it has a p-value $<0.05$. The results of ANOVA also showed that temperature and drying time had a significant impact on viability response. This is evidenced by the insignificant fit shortage, $>0.05$ (0.3702). Therefore, in this study, the viability modelling shows that the temperature factor (40 $\left.-50^{\circ} \mathrm{C}\right)$ and drying time $(0-10 \mathrm{hrs})$ have a significant effect on the AC viability response.

Figure 2 provides a surface overview of the CC dissolved viability response model. The model chosen by the program for the appropriate viability response was a quadratic model with an $\mathrm{R}^{2}$ value of 0.7894 . The $\mathrm{CC}$ mould-yeast viability response model has a p-value (Prob $>$ F) of 0.0474 . This showed that the viability response $(\mathrm{AC})$ can still be described well by the model because it has a $\mathrm{p}$-value $<0.05$. ANOVA results also showed that the temperature and drying time had a significant effect on the viability response. This is evidenced by the insignificant Lack of fit, which is $>0.05$ (0.9033). Therefore, the viability modelling in this study showed that the temperature factor $\left(40-50^{\circ} \mathrm{C}\right)$ and drying time $(0-10 \mathrm{hrs})$ significantly influenced the $\mathrm{CC}$ viability response.

\subsection{Drying process on starters moisture content}

Apart from the drying process, the fermentation process in making starters also plays a role in reducing levels. Pusparani and Yuwono (2014) stated that during the fermentation process, the breakdown of starch by enzymes produced by microorganisms will produce simple sugars such as glucose and accompanied by the release of water. This is known as starch degradation. Starch degradation is characterized by a decrease in the ability of the material to retain water due to the loss of hydroxyl groups. The graph of the relationship between the combination of temperature and drying time to the water content response of AC starters can be seen in Figure 3.

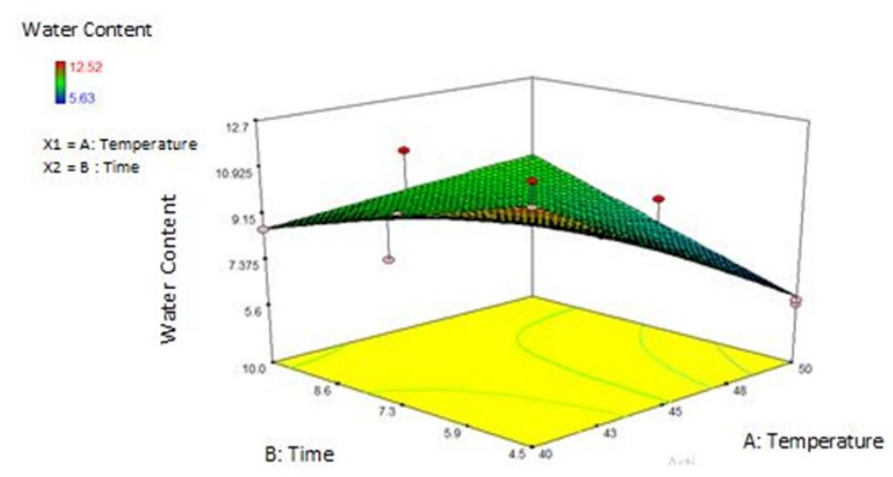

Figure 3. A 3D graphical combination between temperature and drying time to the water content response of $\mathrm{AC}$ starters

The water content response value from AC starters ranged from 5.63 to $12.52 \%$. Figure 3 provides an overview of the AC starters moisture response model. The image's red colour indicated high water content, while the blue colour indicated low water content.

The model chosen by the water content response program was the 2FI model with an $\mathrm{R}^{2}$ value of 0.8382 . The AC moisture response model has a 0.0016 p-value (Prob $>$ F). This shows that the model can still describe the viability response $(\mathrm{AC})$, as it has a $\mathrm{p}$-value $<0.05$. However, the results of ANOVA did not show that the temperature and drying time had a significant effect on the water content response with a significant fit value shortage, $<0.05$ (0.0404). The significant lack of fit value indicates that the temperature $\left(40-50^{\circ} \mathrm{C}\right)$ and drying time parameters (4.5-10 hrs) have no significant effect on the water content response in $\mathrm{AC}$ starters.

Figure 4 shows the graph of the relationship between the combination of temperature and drying time to $\mathrm{CC}$ starter of water content response. The response value to the moisture content generated from CC starters ranged from $5.22-11.53 \%$. The model chosen by the water content response program was the 2FI model with a $0.8209 \mathrm{R}^{2}$ value. The $\mathrm{CC}$ moisture response model has a $0.0023 \mathrm{p}$-value (Prob $>\mathrm{F}$ ). This shows that the model can still describe the viability response (AC), as it has a $p$ -value $<0.05$. However, the results of ANOVA did not show that the temperature and drying time had a significant effect on the water content response with a significant fit value shortage, $<0.05(0.0019)$. The significant lack of fit value indicates that temperature parameters $\left(40-50^{\circ} \mathrm{C}\right)$ and drying time $(4.5-10.0 \mathrm{hrs})$ do not significantly affect the response of moisture content in CC starters. 


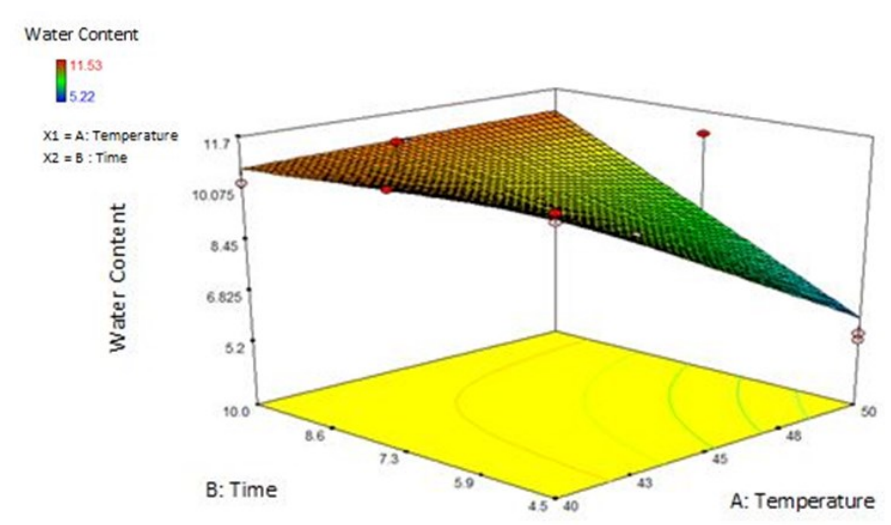

Figure 4. A 3D graphical combination between temperature and drying time to the water content response of CC starters

\subsection{Effect of drying process on water activity value}

Apart from the drying process, the fermentation process in making starters also plays a role in reducing the levels. Pusparani and Yuwono (2014) state that during the fermentation process, the breakdown of starch by enzymes produced by microorganisms will produce simple sugars such as glucose and accompanied by the release of water. This is known as starch degradation. Starch degradation is characterized by a decrease in the ability of the material to retain water due to the loss of hydroxyl groups. The graph of the relationship between the combination of temperature and drying time to the water content response of AC starters can be seen in Figure 5.

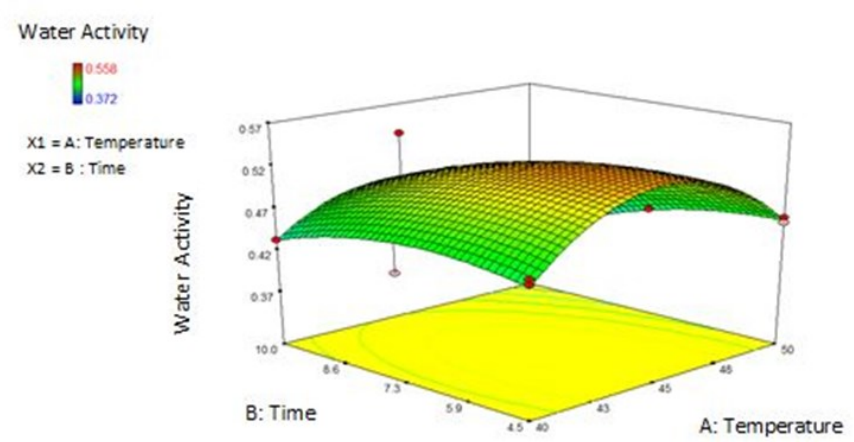

Figure 5. A 3D graphical combination between temperature and drying time to the water activity response of AC starters

Water activity (aw) indicated the amount of free water in a product. Free water in food was needed by growing microorganisms for nutritional processes, a medium for enzymatic reactions, and cellular component synthesis (Chen, 2019). The lower a product's aw value, the lower the risk of chemically or microbiologically damaging the food product. The smaller a product's aw value, the longer the product's shelf life since bacteria, moulds, and yeasts require high aw to grow. Overall, the minimum water activity for bacterial growth is 0.75 , mould is 0.60 , while the minimum yeast growth is 0.80 (Susilo et al., 2019).
Figure 5 shows the graph of the relationship between temperature and drying time to the response of aw starters of AC. The AC-generated response ranged from 0.372 to 0.558 . The red colour shows a high aw, while the blue colour shows a low aw.

The model selected for the appropriate aw response is the quadratic model. Figure 5 provides an overview of the aw response model. The image's red colour indicated a high aw value, while the blue colour indicated a low aw value. The aw (AC) response model has a value of $0.0440 \mathrm{p}$ (Prob $>\mathrm{F}$ ), indicating that the model was significant and can be described well at a 5\% level (pvalue $<0.05)$. However, the ANOVA results showed a significant fit shortage, $<0.05(0.0021)$. This meant that the temperature and drying time does not affect the $\mathrm{AC}$ response.

Meanwhile, the CC-starter aw response ranged from 0.356 to 0.645 . The CC-starters water activity parameter (aw) represented the mean mathematical model. This showed that CC starters' mould-yeast viability and moisture content due to treatment occurs randomly and cannot be explained by the model. Figure 6 shows the graph of the relationship between temperature and drying time to the aw of $\mathrm{CC}$ response.

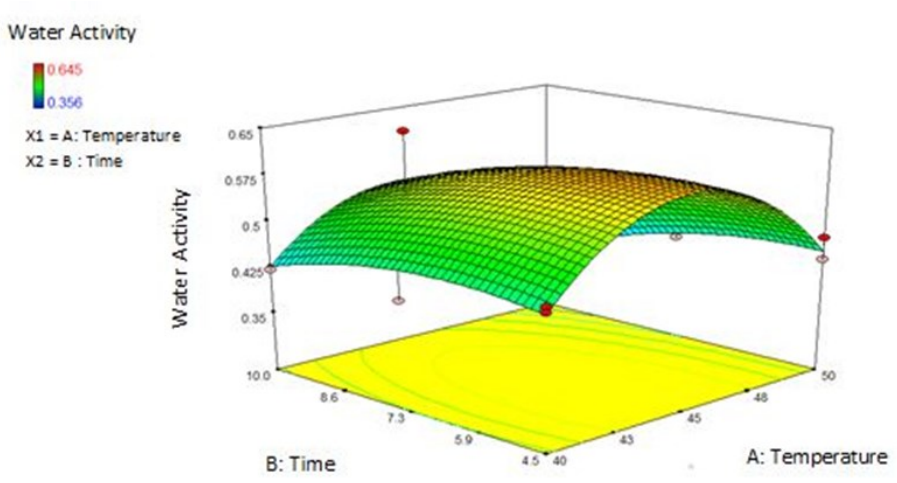

Figure 6. A 3D graphical combination between temperature and drying time to the water activity response of $\mathrm{CC}$ starters

\subsection{Effect of drying process on $\mathrm{pH}$ value}

Acidity or $\mathrm{pH}$ indicates the active concentration of hydrogen ions. The $\mathrm{pH}$ value is used to determine the variety of microorganisms that may grow on the product where each microorganism has a specific growth $\mathrm{pH}$. Pratama et al. (2013) stated that the final results of the $\mathrm{pH}$ value for yeast bread, tempeh yeast, and Lactobacillus plantarum were 4.37 ; 3.43; and 3.93 at 96 hrs of fermentation respectively. For microorganisms, $\mathrm{pH}$ influenced growth and survival. Each type of microorganism has an optimum growth $\mathrm{pH}$ and $\mathrm{pH}$ range. In general, mould and yeast can grow more widely than bacteria (Rahayu and Nurwitri, 2012). Mould has a very wide growth $\mathrm{pH}$ ranged from 2.0-8.5, while yeast has a growth $\mathrm{pH}$ range from 4.0-4.5 and will 
not grow well under alkaline conditions (Muchtadi and Sugiyono, 2013).

The group of microorganisms capable of fermenting food nutrients will convert some or all of the food components into fermented products, such as lactic acid, ethanol, $\mathrm{CO}_{2}$, or other organic acids. Organic acid accumulation causes $\mathrm{pH}$ to decrease during incubation. According to Kartohardjono et al. (2007), $\mathrm{CO}_{2}$ gas is often called acid gas because $\mathrm{CO}_{2}$ gas has acidic properties. $\mathrm{CO}_{2}$ gas contributes to the $\mathrm{pH}$ value. Figure 7 shows the relationship between the combination of temperature and drying time to the $\mathrm{pH}$ response of $\mathrm{AC}$ starters. The $\mathrm{pH}$ response from $\mathrm{AC}$ starters ranges from 3.95 to 4.50 . The image's red colour indicates high $\mathrm{pH}$, while the blue colour indicated low $\mathrm{pH}$.

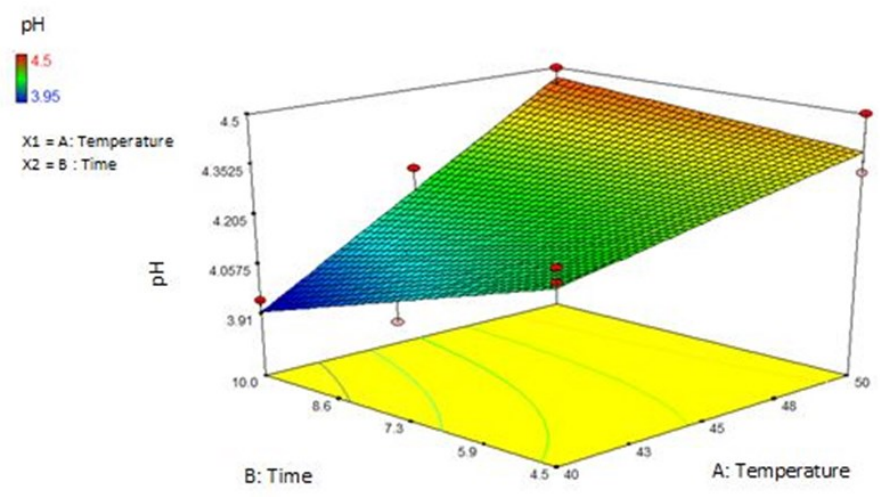

Figure 7. A 3D graphical combination between temperature and drying time to the $\mathrm{pH}$ response of AC starters

The model chosen by the program is the 2FI model with an $\mathrm{R}^{2}$ value of 0.8989 . The $\mathrm{AC} \mathrm{pH}$ response model has $0.0002 \mathrm{p}$-value (Prob $>\mathrm{F}$ ). This shows that the model can still describe the $\mathrm{pH}(\mathrm{AC})$ response as it has a $\mathrm{p}$-value $<0.05$. ANOVA results also showed that the temperature and drying time had a significant $\mathrm{pH}$ response effect. This is evidenced by the insignificant fit lack, $>0.05(0.629)$. Temperature parameters $\left(40-50^{\circ} \mathrm{C}\right)$ and drying time (4.5-10 hrs) have a significant impact on $\mathrm{pH}$ response on $\mathrm{AC}$ starters.

Figure 8 shows the relationship between the combination of temperature and drying time to the $\mathrm{pH}$ response of $\mathrm{CC}$ starters. The model selected by the program is the 2FI model with an $\mathrm{R}^{2}$ value of 0.8479 . The CC pH response model has a 0.0193 p-value (Prob > F). This showed that the model can still describe the $\mathrm{pH}$ (CC) response as it has a p-value $<0.05$. ANOVA results also showed that the temperature and drying time had a significant $\mathrm{pH}$ response effect. This is evidenced by the insignificant fit lack, $>0.05$ (0.0769). Temperature parameters $\left(40-50^{\circ} \mathrm{C}\right)$ and drying time $(4.5-10.0 \mathrm{hrs})$ influenced the $\mathrm{pH}$ response in $\mathrm{AC}$ starters significantly.

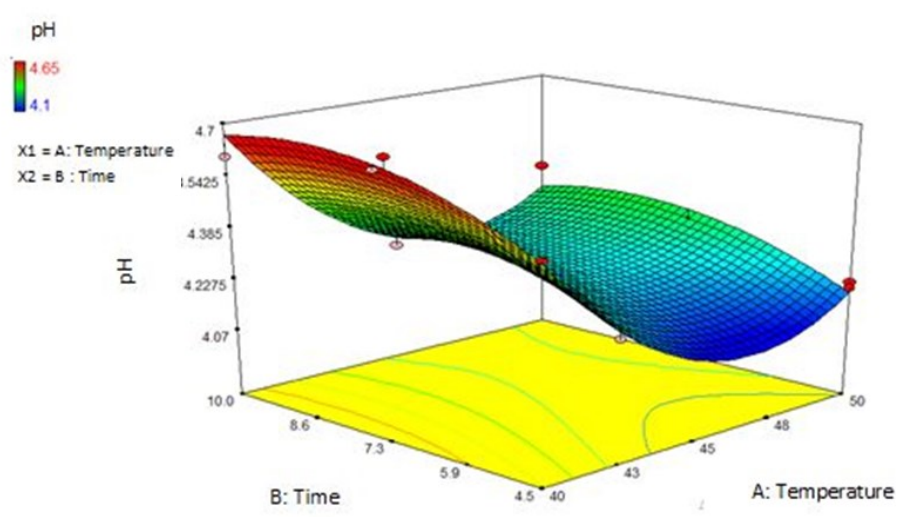

Figure 8. A 3D graphical combination between temperature and drying time on the $\mathrm{pH}$ response of CC starters

\subsection{Process optimization with RSM}

The process optimization stage aimed to obtain the drying process conditions for starting cornflour with an optimal response value based on the specified criteria. Based on the numerical optimization performed, a corn flour solution starts drying formula with the highest desirability value recommended by RSM for each starter, as presented in Table 6 . The desirability value is a parameter showing the best optimization results with a range of $0-10$. The closer to 1.0 the recommended solution can fulfil the desires according to the criteria of the stated objectives and interests (Myers et al., 2009). The combination of drying formula for corn flour starters selected by the AC starter program was a temperature of $40^{\circ} \mathrm{C}$ for $10 \mathrm{hrs}$, while CC starters are $49^{\circ} \mathrm{C}$ for $4.5 \mathrm{hrs}$.

Based on the data in Table 6, the optimum formula for AC starters has a predictive response of $3.929 \mathrm{log}$ $\mathrm{CFU} / \mathrm{g}$ or $8.5 \times 10^{3} \mathrm{CFU} / \mathrm{g}, 8.60 \%$ water content, 0.433 water activity, and $\mathrm{pH}$ 3.91. While the optimum $\mathrm{CC}$ starter formula (Table 6) has a predictive response of $4.958 \log \mathrm{CFU} / \mathrm{g}$ or $9.0 \times 10^{4} \mathrm{CFU} / \mathrm{g}, 6.48 \%$ water content, aw 0.499, and $\mathrm{pH} 4.13$.

\subsection{Results verification}

Result verification was performed at the point with the highest desirability value, respectively, for $\mathrm{AC}$ and

Table 6. Comparison of response predictions with verification results of AC and CC starter

\begin{tabular}{cccccccc}
\hline Starter and response & $\begin{array}{c}\text { Temperature } \\
\left({ }^{\circ} \mathrm{C}\right)\end{array}$ & Time $(\mathrm{Hr})$ & $\begin{array}{c}\text { Viability } \\
(\mathrm{CFU} / \mathrm{g})\end{array}$ & $\begin{array}{c}\text { Water } \\
\text { activity }\left(\mathrm{a}_{\mathrm{w}}\right)\end{array}$ & $\begin{array}{c}\text { Water } \\
\text { content }(\%)\end{array}$ & $\mathrm{pH}$ \\
\hline \multirow{2}{*}{$\mathrm{AC}$} & Prediction & 40 & 10 & 3.929 & 0.433 & 8.60 & 3.91 \\
& Actual & 40 & 10 & 7.944 & 0.425 & 8.90 & 4.05 \\
\hline \multirow{2}{*}{$\mathrm{CC}$} & Prediction & 49 & 4.5 & 4.958 & 0.499 & 6.48 & 4.13 \\
& Actual & 49 & 4.5 & 7.698 & 0.487 & 7.02 & 3.95 \\
\hline
\end{tabular}


$\mathrm{CC}$ starters. The process of starting $\mathrm{AC}$ and $\mathrm{CC}$ was repeated directly using the optimum drying process formula. In addition, the testing process included measuring the total viability of yeast fungi, moisture content, water activity, and $\mathrm{pH}$ directly to generate the actual response variable. The predicted response can be compared with $\mathrm{AC}$ and $\mathrm{CC}$ starters verification results in Table 6.

Based on the verification, there is a significant difference in the value of starter viability between the formula solution suggested by RSM and the verification. According to Rahmawati et al. (2020), the optimization using RSM was unfit to describe the viability response model. This due to an AC-indigenous cocktail yeast mould culture consists of more than one microorganism. So, the activity of AC during the fermentation process varies, because the optimum conditions for growth during incubation for each microorganism vary and maybe there was competition for nutrients by microorganisms varies. On the other hand, the value of 0 in the viability result affected the design of RSM's optimum formula.

\section{Conclusion}

Based on the research results, it can be concluded that the combination of temperature and drying time affects the characteristics of the white corn flour starters. The optimum drying process for $\mathrm{AC}$ starters is at a temperature of $40^{\circ} \mathrm{C}$ for 10.0 hrs with viability characteristics of $7.944 \log \mathrm{CFU} / \mathrm{g}$ or $8.79 \times 10^{7} \mathrm{CFU} / \mathrm{g}$, $8.90 \%$ moisture content, aw 0.425 and $\mathrm{pH} 4.05$. The optimal drying process for $\mathrm{CC}$ starters is at a temperature of $49^{\circ} \mathrm{C}$ for $4.5 \mathrm{hrs}$ with viability characteristics of 7.698 $\log \mathrm{CFU} / \mathrm{g}$ or $4.9 \times 10^{7} \mathrm{CFU} / \mathrm{g}$, the water content of $7.02 \%$, aw 0.487 and $\mathrm{pH} 3.95$.

\section{Conflict of interest}

The authors declare no conflict of interest.

\section{Acknowledgements}

The authors would like to acknowledge the Indonesian Ministry of Research and Higher Education Directorate of Research and Community Empowerment for grant research No. 28/AKM/PNT/2019.

\section{References}

Abasi, S., Mousavi, S.M., Mohebi, M. and Kiani, S. (2009). Effect of time and temperature on moisture content, shrinkage, and rehydration of dried onion. Iranian Journal of Chemical Engineering, 6(3), 5770 .
Aini, N., Hariyadi, P., Muchtadi, T.R. and Andarwulan, N. (2010). Hubungan antara waktu fermentasi grits jagung dengan sifat gelatinisasi tepung jagung putih yang dipengaruhi ukuran partikel. Jurnal Teknologi dan Industri Pangan, 21, 18-24. [In Bahasa Indonesia].

Amanto, B.S., Siswanti and Atmaja, A. (2015). Kinetika pengeringan temu giring (Curcuma heyneana valeton dan van zijp) menggunakan cabinet dryer dengan perlakuan pendahuluan blanching. Jurnal Teknologi Hasil Pertanian, 8(2), 107-114. https:// doi.org/10.20961/jthp.v0i0.12900 [In Bahasa Indonesia].

Anggraeni, Y.P., Pusparini, T. and Yuwono, S.S. (2014). Pengaruh fermentasi alami pada chips ubi jalar (Ipomoea batatas) terhadap sifat fisik tepung ubi jalar terfermentasi. Jurnal Pangan dan Agroindustri, 2(2), 59-69. [In Bahasa Indonesia].

AOAC. (2006). Official Methods of Analysis. Washington D.C., USA: Association of Official Analytical Chemist.

Ayinla, Z.A., Ademakinwa, A.N. and Agboola, F.K. (2017). Studies on the optimization of lipase production by Rhizopus sp. ZAC3 isolated from the contaminated soil of a palm oil processing shed. Journal of Applied Biology and Biotechnology, 5(2), 030-037.

Chen, C. (2019). Relationship between water activity and moisture content in floral honey. Foods, 8(30), 1-18. https://doi.org/10.3390/foods8010030

Farasara, R., Hariyadi, P., Fardiaz, D. and DewantiHariadi, R. (2014). Pasting properties of white corn flours of Anoman 1 and Pulut Harapan varieties as affected by fermentation process. Food and Nutrition Sciences, 5, 2038-2047. https://doi.org/10.4236/ fns. 2014.521215

Fitriani, S. (2008). Pengaruh suhu dan lama pengeringan terhadap beberapa mutu manisan belimbing wuluh (Averrhoa bilimbi L) kering. Jurnal Sagu, 7(1), 3237. [In Bahasa Indonesia].

Herawati, H. (2008). Penentuan umur simpan pada produk pangan. Jurnal Litbang Pertanian, 27(4), 124 -130. [In Bahasa Indonesia].

Kartohardjono, S., Anggara, A., Subihi, S. and Yuliusman, Y. (2007). $\mathrm{CO}_{2}$ Absorption from its mixture with $\mathrm{CH}_{4}$ or $\mathrm{N}_{2}$ through hollow fiber membrane contactor using water as solvent. MAKARA Jurnal of Technology, 11(2), 97-102.

Keshani, S., Luqman, C.A., Nourouzi, M.M., Russly, A.R. and Jamilah, B. (2010). Optimization of concentration process on pomelo fruit juice using response surface methodology (RSM). International 
Food Research Journal, 17(3), 733-742.

Leviana, W. dan Paramita, V. (2017). Pengaruh Suhu Terhadap Kadar Air Dan Aktivitas Air Dalam Bahan Pada Kunyit (Curcuma Longa) Dengan Alat Pengering Electrical Oven. METANA, 13(2), 37-44. https://doi.org/10.14710/metana.v13i2.18012 [In Bahasa Indonesia].

Muchtadi, T.R. dan Sugiyono. (2013). Prinsip Proses dan Teknologi Pangan. Bandung, Indonesia: Alfabeta. [In Bahasa Indonesia].

Myers, R.H., Montgomery, D.C. and Anderson-Cook, C.M. (2009). Response Surface Methodology: Process and Product Optimization Using Designed Experiments. 3rd ed. New York, USA: John Wiley and Sons Inc.

Oliveira, M.N., Sodini, I., Remeuf, R., Tissier, J.P. and Corrieu, G. (2002). Manufacture of fermented lactic beverages containing probiotic cultures. Journal of Food Science, 67(6), 2336-2341. https:// doi.org/10.1111/j.1365-2621.2002.tb09550.x

Passamani, F.R.R., Hernandes, T., Lopes, N.A., Bastos, S.C., Santiago, W.D., Cardoso, M.G and Batista, L.R. (2014). Effect of temperature, water activity, and $\mathrm{pH}$ on growth and production of ochratoxin A by Aspergillus niger and Aspergillus carbonarius from Brazilian grapes. Journal of Food Protection, 77 (11), 1947-52. https://doi.org/10.4315/0362028x.JFP-13-495

Pitt, J.I. and Hocking, A.D. (2009). Fungi and Food Spoilage. $3^{\text {rd }}$ ed. Boston, USA: Springer. https:// doi.org/10.1007/978-0-387-92207-2 2

Pratama, A.Y., Febriani, R.N. dan Gunawan, S. (2013). Pengaruh ragi roti, ragi tempe dan Lactobacillus plantarum terhadap total asam laktat dan $\mathrm{pH}$ pada fermentasi singkong. Journal Teknik ITS, 2(1), F90F92. [In Bahasa Indonesia].

Pusparani, T. dan Yuwono, S.S. (2014). Pengaruh Fermentasi Alami Chips Ubi Jalar (Ipomoea batatas) terhadap Sifat Fisik Tepung Ubi Jalar. Jurnal Pangan dan Agroindustri, 2(4), 137 - 147. [In Bahasa Indonesia].

Rahayu, W.P. and Nurwitri, C.C. (2012). Mikrobiologi Pangan. Bogor, Indonesia: IPB Press. [In Bahasa Indonesia].

Rahmawati, R., Dewanti-Hariyadi, R., Hariyadi, P., Fardiaz, D. and Richana, N. (2013). Isolasi dan identifikasi mikroorganisme selama fermentasi spontan tepung jagung putih. Jurnal Teknologi dan Industri Pangan, 24, 38-44. [In Bahasa Indonesia].

Rahmawati, R., Maulani, R.R. and Saputra, D. (2017). Karakteristik ragi kapang khamir indigenus untuk pembuatan tepung jagung putih lokal fermentasi.
Prosiding Seminar Nasional PATPI 2017. Bandar Lampung, Indonesia: Universitas Lampung. [In Bahasa Indonesia].

Rahmawati, R., Hunaefi, D., Basriman, I., Saputra, D., Aozora, W.D. and Jenie, B.S.L. (2019). The characteristics of "indigenous yeast mold" dried culture using tray dryer. IOP Conference Series: Earth and Environmental Science, 383, 012036. https://doi.org/10.1088/1755-1315/383/1/012036

Rahmawati, R., Hunaefi, D., Basriman, I., Saputra, D., Apriliani, A.A. and Jenie, B.S.L. (2020). Optimization of temperature and drying time of indigenous cocktail yeast mould culture using response surface methodology (RSM). Food Research, 4(2), 389 - 395. https://doi.org/10.26656/ fr.2017.4(2).247

Samaranayake, Y.H. and Samaranayake, L.P. (1994). Candida krusei: Biology, epidemiology, pathogenicity and clinical manifestations of an emerging pathogen. Journal of Medical Microbiology, 41(5), 295-310. https:// doi.org/10.1099/00222615-41-5-295

Sari, D.A., Hakiim, A. and Sukanta. (2017). Pengeringan terasi lokal Karawang: sinar matahari- tray dryer. Jurnal Sains dan Teknologi, 6(2), 311 - 320. https:// doi.org/10.23887/jst-undiksha.v6i2.11867

[In Bahasa Indonesia].

Susilo, A., Rosyidi, D., Jaya, F. and Apriliyani, M.W. (2019). Dasar Tekonologi Hasil Ternak, p. 30-31. Indonesia: UB Press [In Bahasa Indonesia].

Scorzoni, L., de Lucas, M.P., Mesa-Arango, A.C., Fusco -Almeida, A.M., Lozano, E., Cuenca-Estrella, M., Mendes-Giannini, M.J. and Zaragoza, O. (2013). Antifungal Efficacy during Candida krusei Infection in Non-Conventional Models Correlates with the Yeast In Vitro Susceptibility Profile. Plos One, 8(3), 1-13. https://doi.org/10.1371/journal.pone.0060047 